\title{
INTELIJENSI PEMASARAN DALAM UPAYA MEMPERTAHANKAN KEUNGGULAN KOMPETITIF
}

\author{
Miftahus Syukron \\ Slamet \\ Fakultas Ekonomi UIN Maulana Malik Ibrahim Malang \\ Jl. Gajayana No. 50 Malang
}

\begin{abstract}
Marketing intelligence is very important for a company to maintain its competitive advantage in order to face industrial competition. So, if it is done optimally, the information about competitors data can then be achieved and the company can make a decision related to the information. In reality great scale company, which is the object of the research, implement marketing inteligence based on intelligence activities, sources, and factors. Therefore, the company has to adopt the marketing intelligence system to face existing industrial competition and be able to apply it as the procedure. The result shows that: 1) The marketing intelligence employed by great scale companies uses competitive advantage planning and customer value analysis in observing its competitor. 2) The marketing intelligence source employed by great scale companies uses two sources, company environment (internal) and outside environment of the company (external). 3) Marketing intelligence factor employed by great scale companies uses 3 factors. First, the observation of 6 main competitor data including competitor's products, price, promotion, strategy, sale, and other data.Second, competitive advantage factor emphasizing on information processing related to competitor's innovation such as product quality. Third, the salesman factor who employs person in the company to do marketing intelligence in which the company ability is very important in these factors application.
\end{abstract}

Keywords: intelligent activities, intelligence source, intelligence factor in the company

Persaingan bisnis yang semakin meningkat seiring dengan berlakunya sistem pasar bebas pada era abad ke 21 ini mengakibatkan persaingan sudah sangat kompetitif dan ketat. Hal ini akan mengakibatkan tiaptiap perusahaan harus bersaing agar tetap mempertahankan bisnisnya. Dalam era globalisasi perusahaan dipaksa untuk siap meningkatkan daya saingnya.

Strategi bersaing yang diterapkan perusahaan berbeda-beda, bentuk strateginya tergantung potensi dari perusahaan tersebut untuk menjalankan bisnisnya. Perusahaan banyak dituntut untuk tanggap dan menyesuaikan diri dengan bentuk strategi persaingan dari competitor. Selain itu perusahaan juga dituntut untuk membuat suatu langkah strategi bersaing sebelum melaksanakan proses bisnisnya untuk mencapai keberhasilan di pasar. Sehingga Dalam konteks ini Irawan (2011) menyatakan bahwa perlunya beberapa pakar marketing menggunakan pendekatan Marketing intelligence.

Marketing Intelligence (intelijen pemasaran) adalah serangkaian prosedur dan sumber daya yang digunakan para manajer untuk memperoleh informasi sehari-hari mengenai perkembangan yang berkaitan dengan lingkungan pemasaran (Kotler, dkk., 2000: 162). Sistem intelijen pemasaran merupakan bagian dari sistem informasi pemasaran serta sangat erat kaitannya dengan sistem catatan internal perusahaan dan riset pemasaran. Informasi tersebut dapat berasal dari dalam perusahaan sendiri, konsultan riset pemasaran, biro periklanan, pemasok, pelanggan, bahkan pesaing (Kotler, dkk., 2000:162).

Intelijen pemasaran sudah banyak dipakai secara profesional sebagai suatu alat diplomasi untuk menentukan strategi pemasaran oleh perusahaan yang bersaing. Sistem intelijensi pemasaran ini dilakukan perusahaan guna melihat posisi persaingan dalam bisnis yang sejenis, sekaligus menentukan posisi perusahaan dalam menentukan letak persaingan bisnisnya.

Intelijensi pemasaran mempunyai pengaruh besar tidak hanya pada persoalan ekonomi tetapi juga dapat menimbulkan gagasan keunggulan bersaing bahwa suatu perusahaan yang sukses menjalankan intelijen pemasaran akan mengambil posisi yang unik untuk membedakan dirinya dengan pesaing (Lamb, 2001: 377). Faktor persaingan perlu dipertimbangkan dalam menjalankan sistem intelijensi pemasaran perusahaan 
termasuk meningkatkan keunggulan bersaing, memperbaiki struktur industri yang ada, membantu perkembangan pasar dan menghalangi masuknya pesaing baru (Porter, 2008:260).

Keadaan ini memungkinkan perusahaan dapat membentuk strategi pesaing berdasarkan sistem intelijen dalam sumber daya yang ada. Pemanfaatan sumber daya sangat penting dalam manajer untuk menentukan letak perusahaan mengelola sistem intelijen persaingan melalui kemampuan sumber daya manusia, sumber daya fisik, sumber daya pengetahuan, sumber daya permodalan, dan sumber daya infrastruktur (Jajat, 2011:117).

Intelijensi pemasaran sering dikaitkan dengan riset pasar (market research). Aktivitas yang dilakukan memang tidak jauh berbeda. Hanya saja para manajer marketing banyak yang menempatkan pada urusan yang lebih "dalam". Artinya sampai membongkar rahasia kompetitor, baik dilakukan secara halus maupun kasar. Maksudnya cara halus adalah seperti melakukan survei terhadap pelanggan kompetitor maupun observasi atas aktivitas kompetitor di pasar. Sedangkan cara kasar adalah dengan membajak pegawai, melakukan pencurian data, sampai menyusupkan orang di dalam perusahaan. Merujuk dari pendapat Irawan (2011), beberapa tujuan dilakukannya marketing intelligence. Pertama, memberi peringatan awal dari kegiatan kompetitor, kedua, mencari peluang-peluang baru di pasar.

Merujuk dari perkataan Irawan (2011), ada empat pekerjaan utama dari departemen market intelligence atau biro riset. Pekerjaan pertama adalah tahap perencanaan, mereka harus menentukan jenis-jenis informasi yang ingin diperoleh. Tahap kedua adalah mengumpulkan data dan informasi. Aktivitas ini dilakukan dengan cara mengamati atau observasi, membaca hasil publikasi, atau melakukan wawancara dengan berbagai pihak, seperti supplier Pada tahap selanjutnya, diharapkan mereka dapat melakukan analisis. Untuk analisis, perusahaan dapat membuat analisis kualitatif terutama bila ingin melihat tren secara global suatu industri (Irawan, 2011).

Selanjutnya dari penjabaran masalah dalam intelijensi pemasaran, manajer marketing dituntut mulai menyadari bahwa marketing intelligence sangat penting selain untuk keunggulan bersaing, survive dan pertahankan perusahaan dari incaran pihak ketiga yang merusak, maupun para pesaing yang sedang masuk dalam segmen pasar yang sama. Proteksi akan rahasia perusahaan adalah salah satu unsur penting dalam marketing intelligence selain kebutuhan informasi untuk pengembangan pemasaran produk perusahaan. Perusahaan sebaiknya juga mempertajam manfaat adanya intelijensi pemasaran dibanding dengan beban biaya yang ditanggung selama ini.

Perusahaan-perusahaan industri berskala besar yang tersebar di Jawa Timur menjadi obyek dalam penelitian intelijensi pemasaran dengan ciri-ciri jumlah tenaga kerja lebih dari 100 orang, memiliki modal besar yang dihimpun secara kolektif dalam bentuk pemilikan saham, tenaga kerja harus memiliki keterampilan khusus, dan pimpinan perusahaan dipilih melalui uji kemampuan dan kelayakan (fitand profer test). Alasan dipilihnya perusahaan berskala besar dikarenakan kemampuan dari manajer marketingnya yang sudah mengadopsi system intelijen pemasaran.

Dari latar belakang yang telah diuraikan sebelumnya dapat ditarik adanya beberapa permasalahan yang akan diteliti lebih lanjut, yaitu (1) Bagaimana aktivitas melakukan intelijensi pemasaran dalam upaya mempertahankan keunggulan kompetitif di perusahaan Jawa Timur? (2) Faktor apa menjadipenentu manajer dalam melakukan intelijensi pemasaran di perusahaan Jawa Timur?

\section{SISTEM INTELIJEN PEMASARAN}

Dalam perusahaan intelijen pemasaran Kotler \& Amstrong (2008:80) menjelaskan bahwa pihak yang terlibat dalam sistem intelijen meliputi perusahaan, pesaing dan perantara pemasaran. Dalam perancangan sistem intelijen pemasaran, perusahaan berperan sebagai pihak pemroses perhitungan intelijen terhadap pesaing sehingga perusahaan dapat menetapkan tujuan perusahaan, strategi perusahaan secara luas dan kebijakan. Selanjutnya adalah perantara pemasaran yang bertugas membantu perusahaan untuk melaksanakan kegiatan intelijen atas dasar kebijakan manajer.

Pesaing adalah pihak yang terkait dalam objek intelijen pemasaran. Hal ini disebabkan bahwa pesaing sebagai media perusahaan untuk menentukan strategi dan kebijakan manajer (Kotler \& Amstrong, 2008:80). Keputusan-keputusan manajer selain dari pesaing juga didasarkan pada informasi yang mendetail mengenai konsumen. Perpaduan dari data penting dalam intelijen pemasaran dengan menggabungkan informasi deskriptif melalui konsumen memungkinkan manajer dapat menjalankan intelijensi pemasaran (Kotler, 2007:97).

Dapat disimpulkan sistem dari intelijen pemasaran mendeskripsikan dari lingkungan bisnis maka bentuk keterkaitan akan digunakan seperti kemampuan perusahaan untuk mengelola sistem intelijen pemasaran dan data luar dari pesaing. 


\section{Sumber dalam Intelijen Pemasaran}

Pengenalan dalam sistem intelijen pemasaran membuat para perusahaan merancang setiap sumber yang terikat dalam intelijen pemasaran. Lamb (2001: 379) mengatakan terdapat dua sumber dalam intelijen pemasaran yaitu komponen internal dan eksternal dalam perusahaan:

\section{Sumber Intelijen Pemasaran Internal}

Sumber intelijen persaingan adalah komponen yang bergerak di dalam perusahaan untuk memproses data-data pesaing di dalam perusahaan yang menganalisis pengumpulan data dari sumber intelijen pemasaran eksternal. (1) Karyawan perusahaan, dengan berbagai macam keahlian intelijensi pemasaran terhadap seperti pengetahuan tentang pesaing, kompetisi tekhnis, pemahaman pasar atau keahlian lainnya. (2) Database yang independen. Sebuah data internal yang mengolah data-data, baik yang berhubungan dengan data perusahaan maupun data pesaing. (3) Kumpulan studi riset pemasaran. Studi yang meliputi riset pasar terhadap pesaing baik yang meliputi riset produk, penjualan dan promosi dari pesaing.

\section{Sumber Intelijen Pemasaran Eksternal}

Sumber dalam intelijen pemasaran internal menjelaskan proses intelijen pemasaran di dalam perusahaan, Lamb dalam bukunya (2001:280) juga mendeskripsikan intelijen pemasaran eksternal yang lain, seperti: (1) Pakar-pakar. Seorang pakar merupakan seseorang yang memiliki pengetahuan mendalam tentang satu sumber atau aktivitas. (2) Konsultan intelijen pemasaran. Para konsultan intelijen pemasaran menggunakan pengalaman dan keahlian mereka untuk mengumpulkan informasi yang dibutuhkan dengan cepat dan efisien. (3) Pemasok. Pemasok adalah sumber informasi yang bisa didapatkan perusahaan berkaitan dengan pengiriman bahan baku pesaing. Sehingga dari data pemasok perusahaan bisa mengambil langkah lebih baik dari pengiriman bahan baku oleh pesaing maupun kualitas pengiriman bahan baku. (4) Agen pemerintah. Agen dan departemen pemerintah merupakan sumber yang dapat dinilai untuk data intelijen persaingan. (5) Foto-foto. Sebuah perusahaan menggunakan sebuah helikopter untuk mengambil gambar sebuah pabrik. Perusahaan itu sedang mencoba untuk memutuskan apakah perlu menanamkan sejumlah uang dalam divisi elevator yang tidak menguntungkan. (6) Koran dan publikasi lainnya. Surat kabar (koran) terkadang mencetak berita secara berkala tentang keberhasilan, kegagalan, peluang, dan ancaman terhadap perusahaan-perusahaan.(7) Yellow pages. Halaman kuning (yellow pages) adalah salah satu sumber yang paling murah dan paling mudah untuk memperoleh informasi intelijen pemasaran. Yellow pages dapat digunakan untuk intelijen persaingan dengan tujuan sebagai berikut: (a) Untuk menemukan jumlah pesaing dalam suatu pasar tertentu. (b) Untuk mendefinisikan suatu wilayah perdagangan secara realistis. (c) Untuk menemukan para pemasok dan para distributor. (e) Untuk mengali informasi pemasaran dan lini produk. (e) Untuk menentukan ukuran industri. (8) Dewan penasihat. Dapat memberikan nasihat dalam beberapa topik. Teknologi, ekonomi, investasi, politik, lingkungan, sumber daya manusia dan preferensi konsumen merupakan bidang kegiatan yang sering dilakukan oleh dewan penasihat.

\section{METODE}

Penelitian ini termasuk dalam jenis Penelitian kualitatif dengan pendekatan deskriptif yang bertujuan untuk mengetahui subjek penelitian secara holistik seperti perilaku dalam intelijen pemasaran dan tindakan manajer marketing dalam intelijen pemasaran selain itu juga ingin mendeskripsikan bentuk intelijen pemasaran dengan cara deskripsi dalam bentuk katakata dan bahasa sehingga manajer dapat menguraikan tentang upaya intelijen pemasaran terhadap perusahaan beserta aktivitas yang efektif dalam mencapai intelijen pemasaran yang berbasis persaingan bisnis kompetitif.

Adapun sampel dalam penelitian ini dilakukan pada perusahaan di Jawa Timur yang sudah berskala besar dan mempunyai sistem intelijen pemasaran dalam persaingan bisnisnya. Adapun daftar obyek perusahaan secara rinci terdapat pada tabel 1 .

Data yang digunakan dalam penyusunan hasil penelitian ini adalah berupa data primer yang diperoleh langsung dari para manajer marketing dalam menjalankan intelijensi pemasaran, baik melalui wawancara dengan manajer marketing beserta staf yang terkait dalam menjalankan sistem intelijen pemasaran (Slamet, 2005:50).

Teknik pengumpulan data yang digunakan dalam penelitian ini adalah wawancara terstruktur. Adapun tekhnik untuk mendapatkan data, melalui penyebaran angket yang berisi pertanyaan-pertanyaan yang sesuai dengan rumusan masalah. Sementara itu tekhnik penyebarannya mendatangi perusahaan yang menjadi obyek penelitian untuk bertemu dengan manajer marketing atau staf marketing terkait mendapatkan 
Tabel 1. Daftar Obyek Perusahaan

\begin{tabular}{|c|c|c|}
\hline No. & Nama Perusahaan & Alamat \\
\hline 1. & PT. Unilever. Tbk & J1. Rungkut Industri IV/5-11 Surabaya \\
\hline 2. & PT. Yanaprima Hastapersada. Tbk & J1. Pahlawan Sidoarjo \\
\hline 3. & PT. Dexa Medica & J1 Ngagel Jaya Selatan, Gubeng S urabaya. \\
\hline 4. & PT. Maspion & J1. Sawotratap Gedangan Sidoarjo \\
\hline 5. & PT. Kusuma Satria Agriobiotani Perkasa & Jl. Abdul Gani Atas Kota Wisata Batu \\
\hline 6. & PT. Wings Food & J1. Raya Sukomulyo Gresik \\
\hline 7. & PT. Telekomunikasi Indonesia. Tbk & J1. Ketintang Surabaya \\
\hline 8. & PT. Sumber Djaja Perkasa & J1. Pilang Sidoarjo \\
\hline 9. & PT. Stella International. Ltd & J1. Raya Banar Rt 7 Rw 2 Sidoarjo \\
\hline 10. & PT. Tresna Muda Sejati. Ltd & J1. Perak Surabaya \\
\hline 11. & PT. Sierad Produce. Tbk & Jl. Ketimang Wonoayu Sidoarjo \\
\hline 12. & PT. Indoonesia Tri Sembilan & J1. Ngoro Industri Persada Mojokerto \\
\hline 13. & PT. Sasana Artha Finance & J1. Jemursari No 11 Surabaya \\
\hline 14. & PT. Bank Danamon. Tbk & $\begin{array}{l}\text { Jl. Gajah Mada no 5, Blok } 0 \text { RukoAdipura } \\
\text { Mayasari Mojokerto }\end{array}$ \\
\hline 15. & PT. Coin Industri Kimia & Jl. Raya Bligo 17 b Candi Sidoarjo \\
\hline 16. & PT. Japfa Comfeed.Tbk & J1. Raya Popoh Wonoayu Sidoarjo \\
\hline
\end{tabular}

Sumber: data diolah

data aktivitas dan faktor intelijensi pemasaran perusahaan. Informan yang dibutuhkan dalam mendapatkan data penelitian berjumlah 48 orang dengan rincian dari masing-masing perusahaan yang berjumlah 16 perusahaan, 3 orang yang terdiri dari 2 orang pihak internal yaitu manajer marketing dan staf marketing serta satu orang dari pihak eksternal yaitu customer dari masingmasing perusahaan. Alasan pemilihan customer dikarenakan customer mengetahui sejauhmana letak keunggulan kompetitif berdasarkan dari produk perusahaan. Selain itu tekhnik lainnya adalah melalui observasi yang di mana pengamatan secara langsung perusahaan atas kegiatan intelijensi pemasaran.

\section{HASIL DAN PEMBAHASAN}

Perbandingan aktivitas dan faktor intelejensi pemasaran perusahaan yang masuk dalam sampel penelitian adalah seperti tertera pada tabel 2 .

Berdasarkan tabel perbedaan aktivitas dan faktor intelijensi pemasaran perusahaan, dapat dinyatakan bahwa aktivitas mengamati pesaing dalam industri berdasarkan data yaitu menggunakan langkah merancang sistem intelijensi kompetitif yang umumnya perusahaan dalam mengamati sebelumnya didasari dari penciptaan sistem intelijen pemasaran. Sistem intelijen pemasaran yang dibuat perusahaan berdasarkan atas pengamatan poin-poin terpenting dan dilakukan dengan cara yang berbeda-beda. Hal ini sesuai dengan teori Kotler (2003:178) yang mengatakan bahwa dalam aktivitas intelijensi pemasaran terdapat empat langkah utama yaitu: menyusun sistem, mengumpulkan data, mengevaluasi dan menganalisis data dan menyebarluaskan informasi serta menanggapi permintaan.

Namun beberapa perusahaan juga menggunakan aktivitas lain dalam intelijensi pemasaran dengan memakai aktivitas analisis nilai pelanggan. Aktivitas analisis nilai pelanggan yang digunakan perusahaan berdasarkan atas nilai atribut produk yang diamati perusahaan seperti favor dalam PT Tresna Muda Sejati. Ltd, Subsidi dan fasilitas dalam PT Sasana Artha Finance, kualitas Produk dalam PT Yanaprima Hastapersada. Tbk, PT Indonesia Tri Sembilan dan PT Kusuma Satria Agriobiotani Perkasa. Hal ini selaras dengan perkataan Kotler (2003:280) bahwa intelijensi pemasaran yang menggunakan identifikasi atribut utama dalam pelanggan,menilai tingkat kepentingan secara kualitatif dari atribut yang berbeda, menilai kinerja perusahaan dan pesaing pada nilai-nilai pelanggan, menguji bagaimana pelanggan di segmen tertentu dan memantau nilai pelanggan secara berkala disebut analisis nilai pelanggan.

Dalam melaksanakan aktivitasnya terdapat hubungan sumber intelijensi yang digunakan perusahaan antara sumber intelijensi internal dan eksternal. Sumber intelijensi internal yang berperan dalam perusahaan meliputi karyawan perusahaan, data internal dan studi riset perusahaan sedangkan untuk sumber eksternal perusahaan kebanyakan data yang digunakan perusahaan menggunakan informasi dari customer, supplier dan publikasi pesaing.

Dalam menggunakan faktor intelijensi pemasaran, beberapa perusahaan seperti PT Unilever Tbk, 
Tabel 2. Perbandingan Aktivitas dan Faktor Intelijensi Pemasaran Perusahaan

\begin{tabular}{|c|c|c|c|c|}
\hline No. & $\begin{array}{c}\text { Nama } \\
\text { Perusahaan }\end{array}$ & & $\begin{array}{c}\text { Aktivitas Mengamati Pesaing } \\
\text { Dalam Industri } \\
\end{array}$ & $\begin{array}{c}\text { Faktor Penghambat Beserta } \\
\text { Penanganan Masalah }\end{array}$ \\
\hline 1. & $\begin{array}{l}\text { PT. Japfa } \\
\text { Comfeed. } \\
\text { Tbk }\end{array}$ & & $\begin{array}{l}\text { Akti vitas intelijensi pemasaran } \\
\text { yang digunakan adalah } \\
\text { merancang sistem intelijensi } \\
\text { kompetitif. } \\
\text { Akti vitas inte lijensi } \\
\text { pemasarannya adalah meminta } \\
\text { informasi dari pelanggan dan } \\
\text { customer serta me mbandingkan } \\
\text { produk pesaing. } \\
\text { Langkah-langkahnya adalah } \\
\text { mengorek keterangan dari } \\
\text { pelanggan dan supir ekspedisi } \\
\text { dilanjutkan dengan menyamar } \\
\text { sebagai konsumen pesaing. } \\
\text { Yang berperan dalam } \\
\text { melaksanakan intelijensi } \\
\text { pemasaran adalah sales, driver } \\
\text { ekspedisi dan pimpinan. }\end{array}$ & $\begin{array}{l}\text { - Faktor yang digunakan dalam } \\
\text { intelijensi pemasaran adalah } \\
\text { faktor produk, harga dan } \\
\text { strategi pemasaran. } \\
\text { - Hambatannya adalah customer } \\
\text { tidak mau memberikan } \\
\text { informasi } \\
\text { - Cara mengata sinya adalah } \\
\text { memberikan kompensasi } \\
\text { kepada customer dan } \\
\text { menunjukkan bahwa informasi } \\
\text { tersebut sangat penting } \\
\text { - Dampaknya adalah bisa bisa } \\
\text { mempengaruhi harga pasar dan } \\
\text { memberikan keuntungan } \\
\text { perusahaan. } \\
\text { - Keunggulan kompetitif } \\
\text { perusahaan adalah } \\
\text { pengembangan teknologi dalam } \\
\text { keunggulan bersaing. } \\
\text { - Pelanggan mengatakan bahwa } \\
\text { keunggulan perusahaan dari } \\
\text { kualitas produk dan pendekatan } \\
\text { yang dilakukan berupa } \\
\text { pendekatan ke peternak } \\
\text { setempat. }\end{array}$ \\
\hline 2. & $\begin{array}{l}\text { PT. Coin } \\
\text { Industri } \\
\text { Kimia }\end{array}$ & & $\begin{array}{l}\text { Akti vitas inte lijensi pemasaran } \\
\text { yang digunakan adalah } \\
\text { merancang sistem intelijensi } \\
\text { kompetitif. } \\
\text { Akti vitasnya adalah } \\
\text { perbandingan penjualan dan } \\
\text { produksi antara perusahaan } \\
\text { dengan pesaing. } \\
\text { Langkah-langkahnya adalah } \\
\text { melakukan me tode marketing } \\
\text { untuk meningkatkan jumlah } \\
\text { penjualan dan produksi. } \\
\text { Yang berperan dalam aktivitas } \\
\text { adalah marketing dibantu bagian } \\
\text { penjualan } \\
\text { Strateginya melakukan hubungan } \\
\text { baik dengan customer untuk } \\
\text { mendapatkan informasi selain itu } \\
\text { menggunakan media internet dan } \\
\text { berwawasan tinggi dalam } \\
\text { berkomunikasi dengan pesaing. }\end{array}$ & $\begin{array}{l}\text { - Faktor yang digunakan dalam } \\
\text { intelijensi pemasaran adalah } \\
\text { faktor produk, harga dan } \\
\text { strategi pemasaran. } \\
\text { - Hambatannya adalah susahnya } \\
\text { informasi yang masuk dari } \\
\text { customer } \\
\text { - Cara mengata sinya adalah } \\
\text { menjaga hubungan baik dengan } \\
\text { customer } \\
\text { - Dampaknya meningkatkan } \\
\text { kualitas produk, memiliki } \\
\text { metode marketing yang bagus } \\
\text { dan memperbanyak varian } \\
\text { produk yang dijual } \\
\text { - Keunggulan kompetitif } \\
\text { perusahaan adalah memilih } \\
\text { pasar yang baik dalam } \\
\text { keunggulan bersaing. } \\
\text { - Pelanggan mengatakan bahwa } \\
\text { keunggulan perusahaan dari } \\
\text { kualitas produk kuat dan tahan } \\
\text { lama dan pendekatan yang } \\
\text { dilakukan berupa pemasaran di } \\
\text { toko bangunan dan toko lain- } \\
\text { lain. }\end{array}$ \\
\hline
\end{tabular}




\begin{tabular}{|c|c|c|c|c|}
\hline No. & $\begin{array}{c}\text { Nama } \\
\text { Perusahaan }\end{array}$ & & $\begin{array}{c}\text { Aktivitas Mengamati Pesaing } \\
\text { Dalam Industri }\end{array}$ & $\begin{array}{c}\text { Faktor Penghambat Beserta } \\
\text { Penanganan Masalah }\end{array}$ \\
\hline 3. & $\begin{array}{l}\text { PT. Bank } \\
\text { Danamon. } \\
\text { Tbk }\end{array}$ & - & $\begin{array}{l}\text { Aktivitas intelijensi pemasaran } \\
\text { yang digunakan adalah } \\
\text { merancang sistem intelijensi } \\
\text { kompet itif. } \\
\text { Aktivitasnya melakukan } \\
\text { pengamatan pada media cetak, } \\
\text { informasi dunia perbankan dan } \\
\text { nasabah. } \\
\text { Langkah-langkahnya melakukan } \\
\text { survei di lingkungan untuk } \\
\text { mendapatkan data dari konsumen } \\
\text { dan menggali informasi dari } \\
\text { marketing. } \\
\text { Yang berperan adalah para } \\
\text { marketing dan nasabah } \\
\text { Strateginya adalah melakukan } \\
\text { pendekatan terbuka dengan } \\
\text { pesaing. }\end{array}$ & $\begin{array}{l}\text { - Faktor yang digunakan dalam } \\
\text { intelijensi pemasaran adalah } \\
\text { faktor keunggulan kompetitif. } \\
\text { - } \quad \text { Hambatannya adalah tidak } \\
\text { semua informasi akurat. } \\
\text { - Cara mengatasinya dalah } \\
\text { mengetahui data nasabah dan } \\
\text { debitur secara penuh. } \\
\text { - } \quad \text { ampaknya adalah bisa } \\
\text { memasarkan produk-produk } \\
\text { yang dimiliki dengan } \\
\text { keunggulan proses kred it } \\
\text { maupun keu nggu lan lainnya. } \\
\text { Keunggulan kompetit if } \\
\text { perusahaan adalah } \\
\text { menciptakan nilai bagi } \\
\text { nasabah dalam keunggulan } \\
\text { bersaing. } \\
\text { Nasabahmengatakan bahwa } \\
\text { keunggulan perusahaan dari } \\
\text { proses kredit dan pendekatan } \\
\text { yang dilakukan berupa } \\
\text { tawaran sales perbankan ke } \\
\text { nasabah. }\end{array}$ \\
\hline 4. & $\begin{array}{l}\text { PT. Dexa } \\
\text { Medica }\end{array}$ & - & $\begin{array}{l}\text { Akt ivitas intelijensi pemasaran } \\
\text { yang digunakan adalah } \\
\text { merancang sistem intelijensi } \\
\text { kompet itif. } \\
\text { Akt ivitasnya adalah dengan } \\
\text { mengamati produk, program dan } \\
\text { strategi pesaing. } \\
\text { Langkah-langkahnya adalah } \\
\text { mencari tahu kegiatan kompetitor } \\
\text { dan membentuk tim untuk } \\
\text { mengamati kompet itor. } \\
\text { Yang berperan adalah semua tim } \\
\text { pemasaran } \\
\text { Strateginya dengan melakukan } \\
\text { survei secara menyeluru hepada } \\
\text { kompet itor. }\end{array}$ & $\begin{array}{l}\text { - Faktor yang digunakan dalam } \\
\text { intelijensi pemasaran adalah } \\
\text { faktor wiraniaga. } \\
\text { - } \text { Hambatannya sulit nya } \\
\text { memperoleh data valid dari } \\
\text { kompet itor. } \\
\text { Cara mengatasinya deng an } \\
\text { melakukan pendekatan } \\
\text { entertain ke konsumen } \\
\text { kompet itor. } \\
\text { Dampaknya adalah bisa } \\
\text { mengetahui apa saja } \\
\text { kelemahan kompetitor. } \\
\text { Keunggulan kompetitif } \\
\text { perusahaan adalah mencari } \\
\text { segmen baru dalam } \\
\text { keunggulan bersaing. } \\
\text { Pelanggan mengatakan bahwa } \\
\text { keunggulan perusahaan dari } \\
\text { heterogenitas produk dan } \\
\text { pendekatan yang dilakukan } \\
\text { berupa pendekatan ke toko } \\
\text { obat, apotik dan rumah sakit. }\end{array}$ \\
\hline
\end{tabular}

PT Kusuma Satria Agriobiotani Perkasa, PT Sasana Artha Finance, PT Coin Industri Kimia dan PT Japfa Comfeed. Tbk menggunakan faktor 6 pokok data pesaing yang menurut Irawan (2011) menyatakan bahwa perusahaan dalam menganalisis pesaing harus berkonsep pada 6 pokok data pesaing yaitu data produk pesaing, data promosi pesaing, data strategi pesaing, penjualan pesaing, harga pesaing dan data lainnya yang berkaitan dengan penentuan persaingan bisnis perusahaan terhadap pesaing.

Sementara itu beberapa perusahaan juga menggunakan faktor keunggulan kompetitif dalam melakukan intelijensi pemasaran seperti PT Yanaprima Hastapersada. Tbk, PT Maspion, PT Telekomunikasi 
Indonesia, PT Bank Danamon Indonesia. Tbk dan PT Sumber djaja Perkasa, yang di mana dalam melakukan pengamatan letak pemrosesan informasi yang digunakan perusahaan adalah keunggulan utama dari pesaing seperti kualitas produk dan inovasi produk.

Selanjutnya faktor lainnya yang digunakan perusahaan dalam melakukan intelijensi pemasaran menggunakan faktor wiraniaga yang menerapkan kemampuan orang perusahaan untuk menjalankan aktivitas intelijensi pemasaran. Faktor ini diterapkan pada beberapa perusahaan seperti PT Sasana Artha Finance, PT Stella international. Ltd, PT Sierad produce. Tbk, PT Indonesia Tri Sembilan, PT Wings Food dan PT Dexa medica. Dalam penerapannya perusahaan tersebut menempatkan orang-orang yang sudah dilatih untuk mendapatkan informasi dari pesaing serta profesional dalam mencari informasi.

Triangulasi data dari pelanggan menyatakan bahwa dalam mengenali keunggulan kompetitif atas intelijensi pemasaran yang dilakukan perusahaan berskala besar menyatakan sejauh ini pelanggan dapat mengenali keunggulan kompetitif perusahaan berasal dari produk yang ditawarkan seperti keunggulan produk, kekurangan produk serta pendekatan perusahaan dalam melakukan strategi intelijensi terhadap pelanggan. Bentuk keunggulan yang dijelaskan pelanggan bermacam-macam dimulai dari letak kualitas, proses, keberagaman produk dan lain sebagainya, hal itu menunjukkan bahwa perusahaan berskala besar mampu melakukan strategi intelijensi pemasaran berdasarkan penciptaan nilai pelanggan.

\section{KESIMPULAN DAN SARAN}

\section{Kesimpulan}

Dari hasil kesimpulan data yang disajikan di atas, dapat dikemukakan beberapa kesimpulan terkait dengan aktivitas intelijensi pemasaran yang dilakukan perusahaan berskala besar yaitu: (1) Aktivitas yang dilakukan berupa aktivitas merancang keunggulan kompetitif yang prosedurnya berdasarkan empat langkah utama yaitu: menyusun sistem, mengumpulkan data, mengevaluasi dan menganalisis data dan menyebarluaskan informasi serta menanggapi permintaan. (2) Aktivitas lainnya berupa analisis nilai pelanggan yang pengamatannya didasarkan pada nilai atribut pelanggan seperti kualitas produk dan inovasi produk. (3) Penggerak aktivitas intelijensi pemasaran dalam perusahaan berskala besar menggunakan dua sumber yaitu sumber internal perusahaan berupa: karyawan, studi riset dan data eksternal berupa customer, publikasi pesaing dan supplier.

Kesimpulan terkait faktor intelijensi pemasaran yang dilakukan perusahaan berskala besar yaitu: (1) Beberapa perusahaan seperti yang dijelaskan di pembahasan data menggunakan faktor pengamatan 6 pokok data pesaing yang meliputi produk pesaing, harga pesaing, promosi pesaing, penjualan pesaing, strategi pesaing dan data lainnya yang berkaitan dengan pesaing. (2) Beberapa perusahaan juga menggunakan faktor keunggulan kompetitif yang menerapkan pemrosesan data pesaing terkait dengan inovasi yang dilakukan pesaing serta kualitas pesaing. (3) Faktor wiraniaga yang menekankan pada kemampuan orang perusahaan untuk dijadikan alat dalam mengambil data perusahaan juga digunakan dalam melakukan sistem intelijen pemasaran oleh beberapa perusahaan berskala besar sehingga pelatihan dan peningkatan kemampuan wiraniaga dalam mendapatkan data pesaing sangat penting penerapanya.

\section{Saran}

Setelah mengemukakan beberapa kesimpulan, selanjutnya akan disampaikan beberapa saran dalam menggunakan intelijensi pemasaran pada obyek perusahaan yang ada. Adapun saran-saran yang dikemukakan adalah: (1) Untuk menjaga kelangsungan perusahaan, sebaiknya perusahaan harus melakukan aktivitas intelijensi pemasaran agar selalu mendapat informasi yang penting berkaitan dengan perumusan strategi pemasaran perusahaan, (2) Perusahaan harus memperhatikan kondisi persaingan yang semakin ketat sehingga diharapkan dapat merancang persaingan pada keunggulan kompetitif.

Perusahaan harus selalu menjaga hubungan baik dengan para sumber intelijensi pemasaran baik itu agen, supplier, customer bahkan orang dalam perusahaan itu sendiri.

\section{DAFTAR RUJUKAN}

Irawan, H. 2011. Tabloid Marketing. Jakarta.

Jono, H. 2003. IntelijenSebagaillmu. Jakarta: BalaiPustaka.

Kotler, P., \& Keller. 2006. Manajemen Pemasaran Edisi 12. Jakarta: Indeks. 2000. Manajemen Pemasaran Perspektif Asia. Yogyakarta: Andi.

......... 2003. Manajemen Pemasaran Sudut Pandang Asia. Jakarta: Indeks.

Kotler, P., \& Garry, A. 2006. Prinsip-Prinsip Pemasaran. Edisi 12. Jakarta: Erlangga. 
Intelijensi Pemasaran dalam Upaya Mempertahankan Keunggulan Kompetitif

Kotler, P., dkk. 2007. Mastering Marketing Companions in Marketing. Jakarta: Indeks.

Lamb, H., \& McDaniel. 2001. Pemasaran. Jakarta: Salemba Empat.

Porter, Michael, E. 2008. Competitive Advantage (Keunggulan Bersaing). Tangerang: Karisma Publishing Group.

Prastowo, A. 2011. Metode Penelitian Kualitatif Dalam Perspektif Rancangan Penelitian. Yogyakarta: ARRuzz Media.
Prastowo, A. 2011. Menguasai Teknik-teknik Koleksi Data Penelitian Kualitatif. Yogyakarta: Diva Press. Simamora, H. 2000. Manajemen Pemasaran Internasional. Jakarta: Salemba Empat.

Slamet. 2005. Membangun Strategi Bersaing Fakultas Ekonomi UIN Malang (Benchmarking Strategic Approach). Malang. 